\title{
NGOs, Political Protest and Civil Society: Book Review
}

Mahmut Ulas Gozutok

University of Kentucky

\begin{tabular}{|c|c|c|}
\hline & Book title & : NGOs, Political Protest, \\
\hline NGOs, & & and Civil Society \\
\hline POLITICAL & Author & : Carew Boulding \\
\hline PROTEST, AND & Publisher & : Cambridge University \\
\hline CIVIL SOCIETY & Press & \\
\hline EW BOULDING & Year & : 2014 \\
\hline & ISBN & : 9781107065703 \\
\hline & Number of page & $: 232$ \\
\hline & Price & : US\$90 \\
\hline
\end{tabular}

Non-governmental organizations (NGOs) play a key role for providing a platform for citizens to raise their discontents in democratic settings. NGO activities for encouraging democratic public engagement pose no threats against stability in consolidated democratic regimes with effectively functioning political parties. On the other hand, they can be a contentious issue in countries with shaky foundations of democracy. In fact, Huntington (1968) mainly champions in one of his most widely cited works by the civil society literature the idea that associations of social capital such as civil society can have detrimental repercussions on stability and order in infantile democratic regimes since political parties in such contexts are argued to be ill-equipped to handle challenges brought by modernization. On the other hand, primary elements of social capital (i.e. civil society) are acknowledged to be the prerequisites for effective functioning of democracies (Putnam 1994).

The premise of Boulding's work points to a middle-ground between the aforementioned contending views on civil society. Boulding 
argues that civil society organizations are not necessarily tools of amiable and associative networks of human interaction as Putnam (1994) argues. They might also harbor conflictive connotations depending on regime functions of nominal democracies. If nominally democratic regimes have ineffectively functioning political parties, which might fail on their promises for upholding basic human rights, Boulding states that NGOs might encourage people to take their grievances out on the streets in the form of protests, demonstrations and even riots. Occurrence of such events does not necessarily mean that citizens take an anti-democratic and anti-systemic stance against the regime so, motivation provided by NGOs should not be perceived as guidance against democratic gains. Otherwise, if citizen trust in a regime is preserved by actions of the ruling party, then encouragement by NGOs for seeking political action is much more likely to manifest itself in the form of nudging people to the polls instead of organizing street protests. She addresses particular channels NGOs use for motivating people for such actions: NGOs vary depending on their organizational goals and structures. Some can specialize in healthcare and some can offer educational services to citizens. Irrespective of the type of NGO specialization, NGOs are able to provide financial assistance due to the fact that they are internationally funded. These funding resources of NGOs help them train and educate people in their respective specializations, provide a platform for people to gather and encourage people to raise their concerns if democratic principles are at stake. This book deepens analytical insights about the role of NGOs on guiding people to vote or riot in nominally democratic countries with extensive empirical analysis.

After empirically analyzing the link between association with NGOs and the probability of voting or protesting in Bolivia as well as in Latin America, she then extends it to a sample of developing democracies in the world. She mainly finds that less stably functioning and more crisisprone democracies experience higher probability of public protests against the regime as a result of increasing contact with civil society and NGOs. Similar patterns hold true regardless of the context she investigates. In this respect, how NGOs play a role on encouraging people whether to vote or protest against the government depending on the extent of stable functioning of political system does not differ between Latin American democracies and other analyzed nominally democratic countries in the world. 
To elaborate on Boulding's main arguments more extensively, I shall open up what is meant by effective functioning of a political system. NGOs can have direct or indirect effects on mobilization of the resourcepoor people in nominally democratic countries. If such countries have relatively stronger systems, in which elections are fairly competitive, electoral corruption is low and the government does not repress diverse opinions, then citizens can feel that they might have a chance to affect the outcome by going to the polls. Hence, NGOs can mobilize citizens to vote. Whereas, if political institutionalization is fairly weak, then such organizations can encourage people to take their grievances out on the streets by protesting against the government. Here, what type of function a NGO might serve is conditional upon the domestic political context and the degree of political institutionalization in nominally democratic regimes in developing countries.

Even though Boulding sets up her theoretical point of departure as a response to Huntington's assumptions about the ramifications of civil society on the process of democratization, such a bold attempt is not entirely justified since Huntington's work (1968) is not only interested in providing prescriptions on how to solidify democratization.For Huntington, the presence of a disciplined party structure can establish order in both democratic and authoritarian regimes (i.e. the Soviet Russia during 1960s) with stable political institutionalization, and this assumption is not only confined to the context of democratic regimes. On the other hand, for Boulding, effectively functioning political parties should at least perform their role of upholding the basic democratic principles in a relatively effective manner so that through contact with NGOs, citizens are encouraged to vote rather than attempting protests or riots, which might disrupt order in the world of Huntington. To Huntington, order and regime stability can be ensured either in a democracy or an authoritarian regime regardless of the fact that the regime oppresses its citizens under such conditions. Whereas, Boulding argues that increasing oppression in nominally democratic states can backfire and trigger waves of protests by citizens, who are in contact with NGOs, thus such an outcome might destabilize the democratization experiment.

All in all, this book provides an empirically-backed refreshing perspective on dual roles that NGOs play in encouraging people towards action for democratic progress in nominally democratic countries. It acts as a bridge between the literature, which emphasizes deconstructive 
effects of civil society on countries experiencing democratization, and the one, which strongly highlights democracy-solidifying impacts of social capital and civil society. It provides the readers with striking empirical evidence, which points to the correlation between people's contact with NGOs and their tendency to go to polls or riot depending on the extent of freedom a regime provides and how trustworthy it is perceived by citizens. However, its main theoretical point of departure lacks the logical connection withthe way Huntington frames his argument to treat civil society as a byproduct of modernization in painful experiments of democratization.

The subject matter of this book is also relevant to Indonesia. Indonesia's experimentation with democratization began less than 20 years ago and, as a relatively young democracy with growing pains, Indonesia can gain immensely from the rising number of NGOs. As the domestic presence of NGOs in Indonesia grows, so does their likelihood to recruit more members from Indonesian society and to increase their political participation with their resources. The norm diffusion impact of NGOs can help increase political participation from disgruntled Indonesian people, who do not go to polls, thereby pulling up voter turnout, which was less than 70\% in the last presidential election in 2014. 